\title{
EVALUASI KESESUAIAN LOKASI DAN JANGKAUAN PELAYANAN SEKOLAH MENENGAH UMUM DI KECAMATAN KEBAKKRAMAT KABUPATEN KARANGANYAR
}

\author{
G.P.Pancarrani ${ }^{a}$, B.Pigawati ${ }^{b}$ \\ ${ }^{a}$ Universitas Diponegoro, Indonesia, email: gloriaputripancarrani@gmail.com \\ ${ }^{b}$ Universitas Diponegoro, Indonesia, email: bitta.pigawati@gmail.com
}

Article Info;

Received:

6 September 2014

in revised form:

16 September 2014

Accepted:

19 September 2014

Available Online:

1 October 2014

\section{Keywords:}

Suitability of the

Location, Range of

Services, Senior High

School,

Kebakkramat

Subdistrict

Info Artikel;

Diterima:

6 September 2014

Hasil Revisi :

16 September 2014

Disetujui:

19 September 2014

Publikasi On-Line:

1 Oktober 2014

Kata kunci:

Kesesuaian Lokasi, Jangkauan

Pelayanan, Sekolah

Menegah Umum,

Kecamatan

Kebakkramat

Abstract: Senior high school facilities is one of the settlement environment facilities that become supported facilities of settlement area. Determine of education facilities location is determined based location of student. The purpose of this condition is to make it easy student to range this education facilities location. Determine of education facilities location has been manage by government (The Regulation of ministre of Public Works No. 41/PRT/M/2007). Kecamatan Kebakkramat Kabupaten Karanganyar have three senior high school facilities. Now, there are still have a student that must do acsess the education facilities too far. The purpose of this research is to evaluation suitability of the location and range of service of senior high school facilities in Kecamatan Kebakkramat Kabupaten Karanganyar with quantitative approach. Instrument of this research used observation, interview, and kuesioner with descriptive and spatial analytical techniques. Spatial analytical techniques used to knows region function and distribution of location facilities that get from remote sensing. The research result shows location facilities and range of service of senior high school in Kecamatan Kebakkramat Kabupaten Karanganyar is suitable that there are cultivation region, have a road link and mass transportation, there are not in disaster region, and have a good acsess.

region, and have a good acsess.

\begin{abstract}
Abstrak: Fasilitas $p$ endidikan sekolah menengah umum merupakan salah satu sarana lingkungan perumahan dan permukiman yang menjadi fasilitas penunjang kawasan permukiman. Penentuan lokasi fasilitas pendidikan sekolah menengah umum ditentukan berdasarkan keberadaan lokasi siswa yang memanfaatkan fasilitas tersebut. Hal ini bertujuan untuk memudahkan siswa dalam menjangkau lokasi fasilitas pendidikan. Penentuan lokasi fasilitas pendidikan sekolah menengah umum sudah diatur pemerintah dalam Peraturan Menteri Pekerjaan Umum No. 41/PRT/M/2007. Kecamatan Kebakkramat Kabupaten Karanganyar memiliki tiga fasilitas pendidikan sekolah menengah umum. Pada kondisi eksisting masih terdapat beberapa siswa yang harus menempuh jarak yang cukup jauh untuk menjangkau fasilitas pendidikan tersebut. Penelitian ini bertujuan untuk mengevaluasi kesesuaian lokasi fasilitas dan jangkauan pelayanan sekolah menegah umum di Kecamatan Kebakkramat Kabupaten Karanganyar dengan menggunakan pendekatan kuantitatif. Instrumen penelitian yang digunakan adalah observasi, wawancara, dan kuesioner dengan teknik analisis deskriptif dan spasial. Teknik analisis spasial digunakan untuk mengetahui fungsi kawasan dan persebaran lokasi fasilitas yang diperoleh dari data citra satelit. Hasil penelitian menunjukkan bahwa lokasi fasilitas dan jangkauan pelayanan sekolah menengah umum di Kecamatan Kebakkramat Kabupaten Karanganyar telah sesuai yakni berada pada kawasan budidaya, dilalui jaringan jalan dan transportasi umum, tidak berada pada kawasan rawan bencana, dan memiliki akses yang yang cukup baik.
\end{abstract}

\section{PENDAHULUAN}

Kawasan permukiman merupakan lingkungan tempat tinggal dan tempat kegiatan yang mendukung peri kehidupan dan penghidupan masyarakat sekaligus menciptakan interaksi sosial (Peraturan Menteri Pekerjaan Umum No. 41/PRT/M/2007). Terdapat beberapa ketentuan umum dalam pemanfaatan kawasan 
permukiman, salah satu diantaranya adalah pemanfaatan dan pengelolaan kawasan permukiman harus didukung oleh ketersediaan utilitas umum (jalan, drainase, air bersih, sanitasi, persampahan, jaringan listrik, dan jaringan telekomunikasi) dan fasilitas umum atau fasilitas penunjang permukiman (kesehatan, pendidikan, peribadatan). Salah satu fasilitas penunjang permukiman yang sangat dibutuhkan keberadaannya adalah fasilitas pendidikan.

Menurut Tap MPRS No XXVI/MPRS/1966, pendidikan memiliki tujuan penting yakni membentuk manusia pancasila sejati. Tinggi rendahnya kualitas hidup masyarakat suatu wilayah dipengaruhi oleh tingkat pendidikannya, maka pendidikan merupakan sarana penting dalam menunjang keberadaan suatu kota. Kecamatan Kebakkramat Kabupaten Karanganyar memiliki tiga fasilitas pendidikan sekolah menengah umum yang terdiri dari dua sekolah menengah atas (SMA) dan satu sekolah menengah kejuruan (SMK). Pada kondisi eksisting, masih terdapat beberapa siswa yang harus menempuh jarak yang cukup jauh untuk menjangkau fasilitas pendidikan tersebut. Keberadaan suatu fasilitas pendidikan di suatu wilayah atau kota tidak hanya sebatas ada atau tidaknya ketersediaan fasilitas tersebut, namun fasilitas pendidikan harus mampu memberikan jangkauan pelayanan minimal agar dapat dijangkau siswa. Peta citra dan peta lokasi fasilitas pendidikan dapat dilihat pada gambar 1 dan 2.

Gambar 1. Peta Citra Kecamatan Kebakkramat, (RDTR Kecamatan Kebakkramat, 2013)

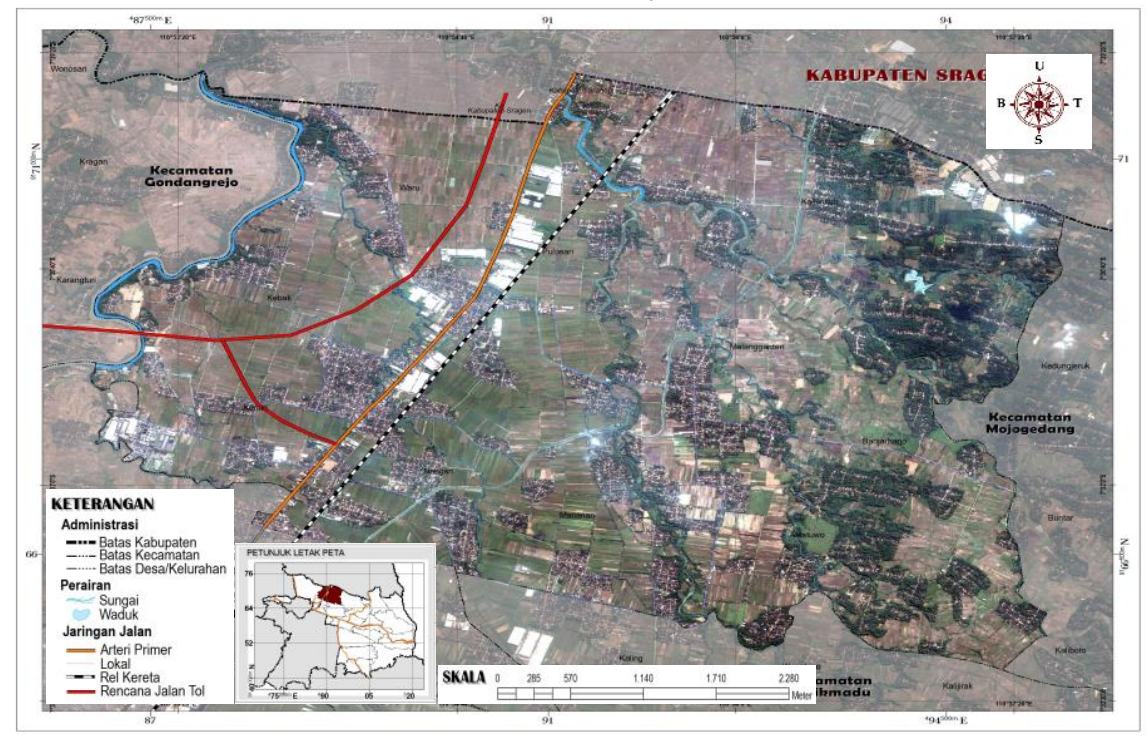

Gambar 2. Peta Lokasi Fasilitas Pendidikan SMU Kecamatan Kebakkramat, (Bappeda, 2011)

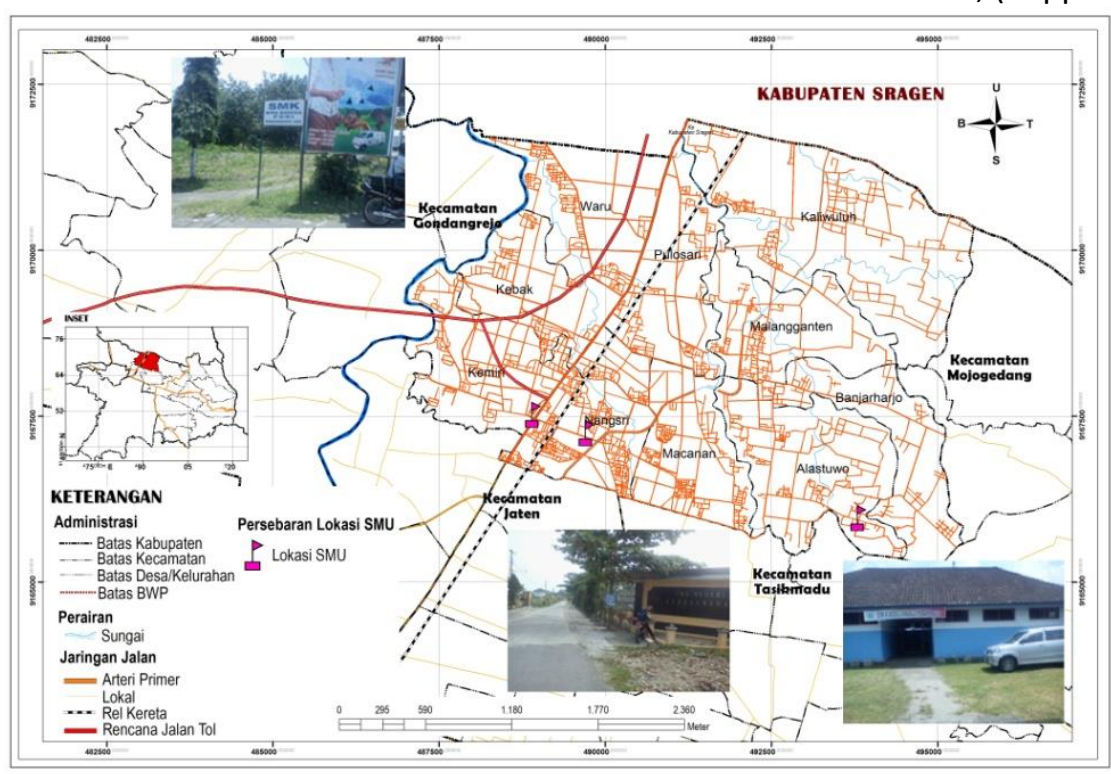


Berdasarkan latar belakang tersebut, penelitian ini bermaksud untuk melengkapi analisis yang telah dilakukan dalam dokumen Rencana Detail Tata Ruang Kecamatan Kebakkramat Tahun 2013-2033. Khususnya analisis kesesuaian lokasi dan jangkauan pelayanan fasilitas pendidikan. Penelitian ini bertujuan untuk mengevaluasi kesesuaian lokasi dan jangkauan pelayanan sekolah menengah umum di Kecamatan Kebakkramat Kabupaten Karanganyar.

\section{DATA DAN METODE}

\subsection{Kesesuaian Lokasi}

Kesesuaian lokasi fasilitas pendidikan sekolah menengah umum dapat dilihat dari fungsi kawasan, keterkaitan lokasi fasilitas pendidikan sekolah menengah umum terhadap lokasi persebaran permukiman, daerah rawan bencana, dan aksesibilitas terhadap lokasi fasilitas pendidikan sekolah menengah umum. Evaluasi Kesesuaian Lokasi dan Jangkauan Pelayanan Sekolah Menengah Umum di Kecamatan Kebakkramat Kabupaten Karanganyar dievaluasi berdasarkan acuan sebagai berikut:

- Fungsi kawasan

Berdasarkan SK Menteri Kehutanan No. 837/UM/11/1980 dan No.683/KPTS/UM/8/1982, fungsi kawasan (budidaya, penyangga, atau lindung) dapat ditentukan dengan menggunakan kriteria kelerengan, curah hujan, dan jenis tanah.

- Sebaran lokasi fasilitas pendidikan sekolah menengah umum

Peraturan Menteri Pekerjaan Umum No. 41/PRT/M/2007 digunakan untuk mengetahui sebaran lokasi fasilitas pendidikan sekolah menengah umum terhadap lokasi permukiman.

- Daerah rawan bencana

Berdasarkan UU nomor 24 tahun 2007 tentang penaggulangan bencana, kawasan rawan bencana termasuk dalam kawasan lindung yang ditetapkan dengan fungsi utama melindungi kelestarian lingkungan hidup yang mencakup sumber daya alam dan sumber daya buatan.

- Aksesibilitas terhadap lokasi fasilitas sekolah menengah umum

Berdasarkan Peraturan Menteri Pekerjaan Umum No. 41/PRT/M/2007, suatu kawasan permukiman harus tersedia jaringan jalan serta dijangkau oleh moda transportasi umum. Menurut Bintarto (1989), tingkat aksesibilitas permukiman dipengaruhi oleh 2 faktor yaitu jaringan jalan dan moda transportasi. Analisis aksesibilitas terhadap lokasi fasilitas pendidikan sekolah menengah umum dipengaruhi oleh jaringan jalan dan moda transportasi yang melalui sekolah menengah umum

\subsection{Jangkauan Pelayanan}

Analisis jangkauan pelayanan lokasi fasilitas sekolah menengah umum dilakukan dengan menganalisis jangkauan pelayanan eksisting dengan standar pemenuhan fasilitas menurut Surat Keputusan Menteri Pekerjaan Umum No. 20/KPTS/1986. Penelitian yang berjudul evaluasi kesesuaian lokasi dan jangkauan pelayanan fasilitas pendidikan sekolah menengah umum di Kecamatan Kebakkramat Kabupaten Karanganyar menggunakan pendekatan kualitatif dan kuantitatif. Pengumpulan data primer dilakukan dengan menggunakan instrumen berupa observasi, wawancara, dan kuesioner. Sementara pengumpulan data sekunder dilakukan dengan survey instansional dan telaah dokumen. Untuk menentukan jumlah sampel, teknik sampling yang digunakan adalah simple random sampling dengan ukuran sampel 267 (tingkat kesalahan 5\%). Teknik analisis yang digunakan adalah deskriptif dan spasial. Teknik analisis spasial digunakan untuk mengetahui fungsi kawasan dan persebaran lokasi fasilitas yang diperoleh dari data citra satelit. Fungsi spasial yang digunakan diantaranta query, scoring, overlay, dan buffer. Untuk lebih jelasnya, kerangka analisis dapat dilihat pada gambar 3. 
Gambar 3. Kerangka Analisis (Hasil Analisis, 2014)

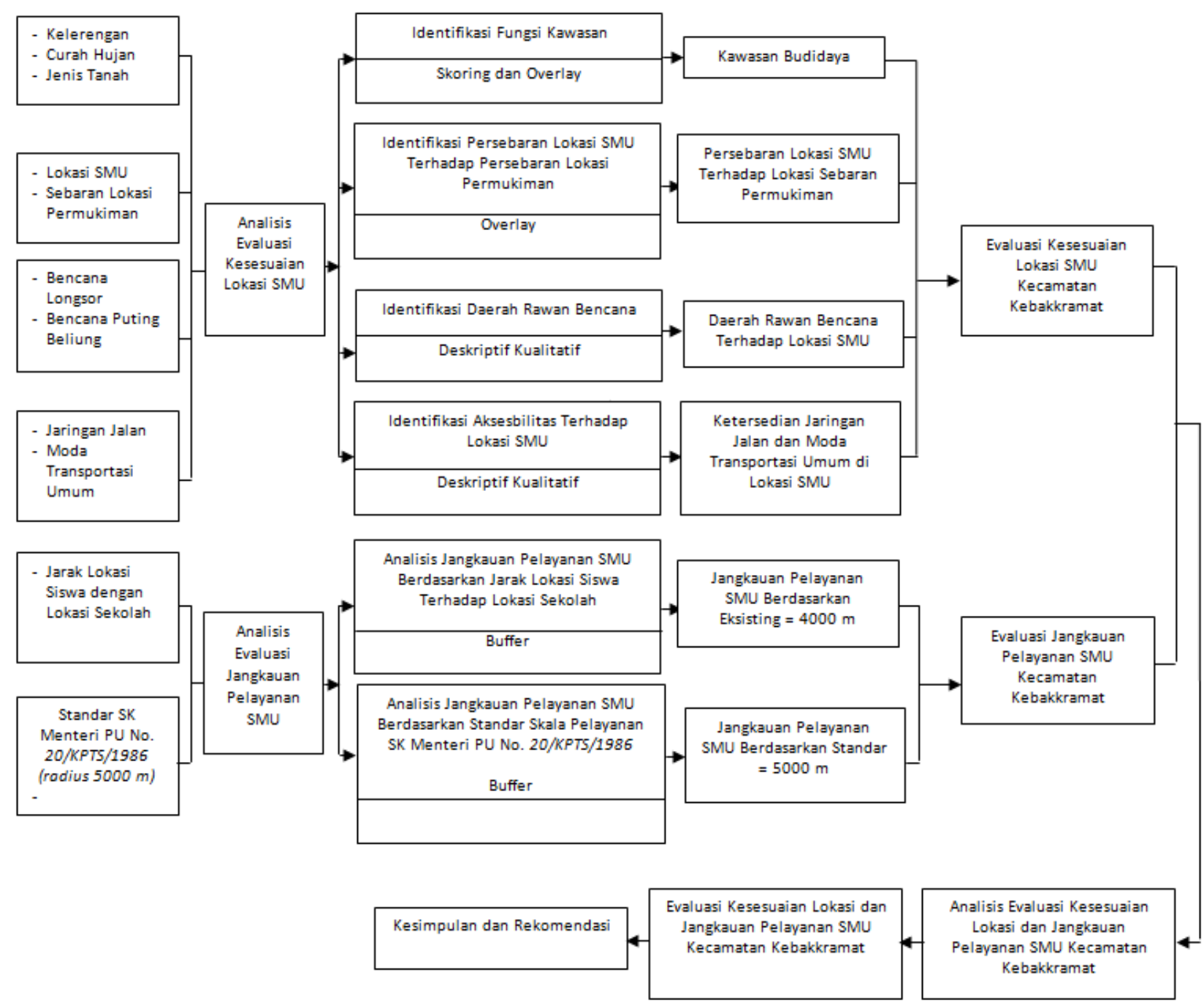

\section{HASIL DAN PEMBAHASAN}

\subsection{Analisis Evaluasi Kesesuaian Lokasi SMU Di Kecamatan Kebakkramat}

Kesesuaian lokasi fasilitas pendidikan sekolah menengah umum di Kecamatan Kebakkramat dapat dilihat dari fungsi kawasan, persebaran lokasinya, daerah rawan bencana dan tingkat aksesibilitas.

\section{Identifikasi Fungsi Kawasan}

Lokasi SMA Negeri Kebakkramat berada di Desa Nangsri, SMK Bina Bangsa berada di Desa Kemiri, dan SMK Widya Mandala berada di Desa Alastuwo. Dilihat dari kelerengannya, ketiga wilayah desa tersebut memiliki kelerengan antara 0-8\% (landai). Intensitas curah hujan yang terjadi di Kecamatan Kebakkramat rata-rata antara 15,46-18,04 mm/hari sehingga termasuk dalam kategori intensitas rendah. Dilihat dari jenis tanahnya, Desa Nangsri dan Desa Kemiri memiliki jenis tanah aluvial kelabu, sementara Desa Alastuwo memiliki jenis tanah latosol coklat. Kedua jenis tanah tersebut cocok dibangun sebagai kawasan permukiman atau fasilitas penunjang lain karena sifatnya yang tidak peka terhadap erosi dan plastis terhadap air. Dengan demikian, berdasarkan kondisi kelerengan, intensitas hujan rata-rata dan jenis tanahnya maka lokasi fasilitas pendidikan sekolah menengah umum di Kecamatan Kebakkramat berada pada fungsi kawasan kawasan budidaya. Untuk lebih jelasnya dapat dilihat pada tabel 1. 
Tabel 1. Fungsi Kawasan di Kecamatan Kebakkramat

\begin{tabular}{|l|c|c|c|c|}
\hline \multicolumn{1}{|c|}{ Desa } & Kelerengan & Jenis Tanah & $\begin{array}{c}\text { Curah Hujan } \\
(\mathbf{m m} / \mathbf{h a r i})\end{array}$ & $\begin{array}{c}\text { Fungsi } \\
\text { Kawasan }\end{array}$ \\
\hline Kemiri & $0-8 \%$ & Aluvial Kelabu & $15,46-18,04$ & Budidaya \\
\hline Nangsri & $0-8 \%$ & Aluvial Kelabu & $15,46-18,04$ & Budidaya \\
\hline Macanan & $0-8 \%$ & Latosol Coklat & $15,46-18,04$ & Budidaya \\
\hline Alastuwo & $0-8 \%$ & Latosol Coklat & $15,46-18,04$ & Budidaya \\
\hline Banjarharjo & $0-8 \%$ & Latosol Coklat & $15,46-18,04$ & Budidaya \\
\hline Malanggaten & $0-8 \%$ & Aluvial Kelabu & $15,46-18,04$ & Budidaya \\
\hline Kaliwuluh & $0-8 \%$ & Latosol Coklat & $15,46-18,04$ & Budidaya \\
\hline Pulosari & $0-8 \%$ & Aluvial Kelabu & $15,46-18,04$ & Budidaya \\
\hline Kebak & $0-8 \%$ & Aluvial Kelabu & $15,46-18,04$ & Budidaya \\
\hline Waru & $0-8 \%$ & Aluvial Kelabu & $15,46-18,04$ & Budidaya \\
\hline
\end{tabular}

2. Identifikasi Persebaran Lokasi SMU terhadap Persebaran Lokasi Permukiman

Lokasi fasilitas pendidikan sekolah menengah umum dapat dikatakan sesuai apabila memenuhi salah satu kriteria yang tertuang dalam Peraturan Menteri Pekerjaan Umum No. 41/PRT/M/2007 yakni berada dalam lingkup kawasan permukiman. Lokasi fasilitas pendidikan sekolah menengah umum di Kecamatan Kebakkramat yang berada di tiga desa yakni Desa Nangsri, Desa Kemiri dan Desa Alastuwo sudah sesuai dengan ketentuan yang ada dimana lokasi fasilitas pendidikan sekolah menengah umum berada di dalam kawasan permukiman yang dilewati jaringan jalan yang kondisinya cukup baik dan beberapa jenis transportasi umum.

\section{Identifikasi Daerah Rawan Bencana}

Lokasi fasilitas pendidikan sekolah menengah umum di Kecamatan Kebakkramat tidak berada di daerah rawan bencana. Secara umum, Kecamatan Kebakkramat rawan akan bencana banjir dan puting beliung. Desa Kaliwuluh, Desa Malangganten dan sebagian kecil di bagian utara Desa Banjarharjo. Termasuk wilayah desa yang rawan akan bencana putting beliung. Sementara, sebagian wilayah Desa Kemiri di bagian barat rawan akan bencana banjir. Untuk wilayah desa yang bebas bencana diantaranya Desa Alastuwo dan Desa Nangsri. Dengan demikian, lokasi fasilitas pendidikan sekolah menengah umum yang rawan akan bencana banjir hanya terdapat di Desa Kemiri. Namun, wilayah Desa Kemiri yang rawan akan bencana banjir berada di bagian barat, sementara lokasi fasilitas pendidikan sekolah menengah umum yang ada di Desa Kemiri berada di ujung bagian paling timur desa tersebut. Sehingga ketiga lokasi fasilitas pendidikan sekolah menegah umum di Kecamatan Kebakkramat tidak berada di dalam daerah yang berpotensi akan rawan bencana baik puting beliung maupun bencana banjir.

4. Identifikasi Aksesibilitas Terhadap Lokasi SMU Kecamatan Kebakkramat

Aksesibilitas dapat dilihat dari 2 faktor yakni jaringan jalan dan moda transportasi umum. Kondisi jalan yang melewati ketiga lokasi fasilitas sekolah menengah umum diKecamatan Kebakkramat cukup baik. SMK Bina Bangsa yang berada di Desa Kemiri dilewati oleh jalan arteri primer yang menghubungkan Kota Solo dengan Kabupaten Sragen. Sementara, meskipun SMA N Kebakkramat dan SMK Widya Mandala yang berada di Desa Nangsri dan Desa Alastuwo hanya dilalui oleh jalan lokal sekunder namun kondisi jalan di kedua wilayah desa ini cukup baik dilihat dari perkerasan jalannya yang berupa aspal dan tidak terdapat keretakan atau lubang-lubang besar.

Moda transportasi umum yang melewati atau menuju lokasi fasilitas pendidikan sekolah menengah umum tersebut cukup beragam. Moda transportasi umum yang melewati SMA N Kebakkramat dan SMK Widya Mandala yang berada di Desa Nangsri dan Desa Alastuwo berupa becak, angkudes dan ojek. Sementara moda transportasi umum yang melewati SMK Bina Bangsa berupa angkot, bus kota, dan bus antar kota. Analisis evaluasi kesesuaian lokasi fasilitas pendidikan sekolah menengah umum berdasarkan fungsi kawasan, persebaran lokasinya, daerah rawan bencana dan tingkat aksesibilitas dapat dilihat pada gambar 4. 
Gambar 4. Peta Evaluasi Kesesuaian Lokasi SMU di Kecamatan Kebakkramat (Hasil Analisis, 2014)

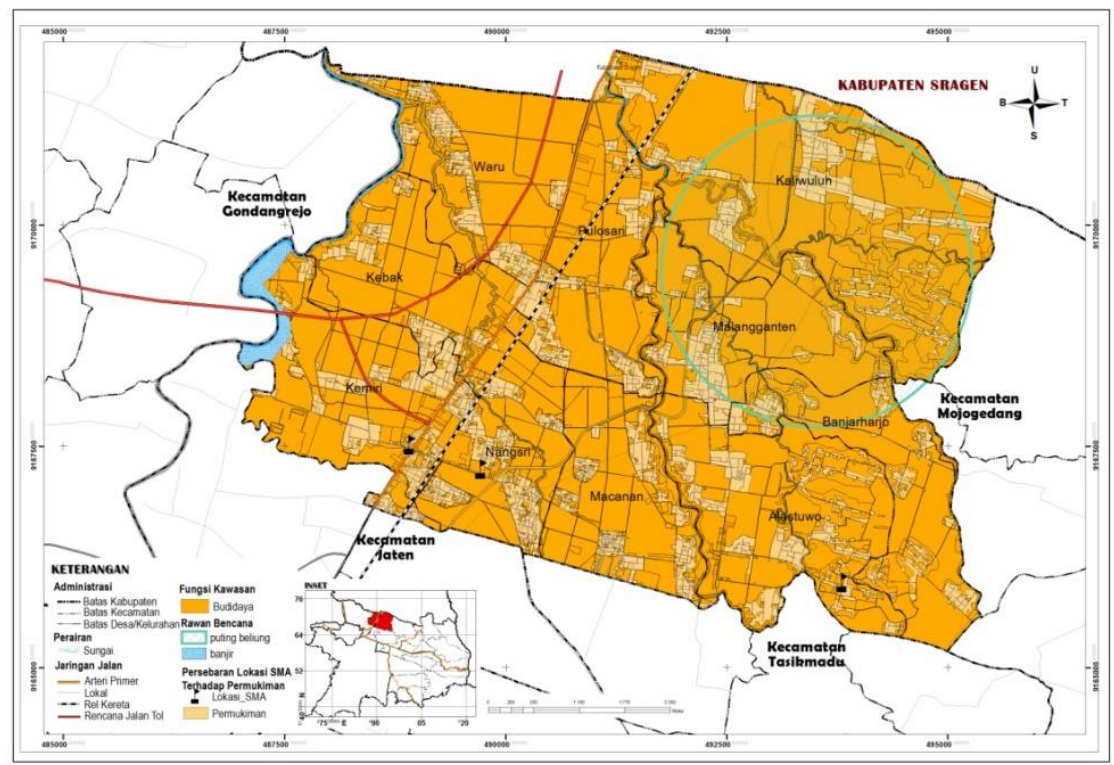

3.2 Analisis Evaluasi Jangkauan Pelayanan SMU di Kecamatan Kebakkramat

1. Jangkauan Pelayanan Berdasarkan SK Menteri Pekerjaan Umum No. 20/KPTS/1986

Berdasarkan SK Menteri Pekerjaan Umum No. 20/KPTS/1986, fasilitas pendidikan SMU sederajat memiliki radius jangkauan pelayanan tertentu untuk skala kecamatan dengan radius jangkauan sejauh 5000 meter. Sehingga dapat dikatakan daerah yang berada di dalam jangkauan pelayanan tersebut merupakan daerah yang sudah terlayani fasilitas pendidikan SMU sederajat, sedangkan daerah yang berada di luar jangkauan pelayanan merupakan daerah yang belum terlayani. Kecamatan Kebakkramat memiliki 3 fasilitas pendidikan sekolah menengah umum yang tersebar di tiga desa yakni Desa Kemiri, Desa Nangsri, dan Desa Alastuwo. Ketiga fasilitas pendidikan tersebut harus menjangkau 10 wilayah desa yang ada di Kecamatan Kebakkramat. Berdasarkan hasil analisis spasial dengan menggunakan fungsi buffer, seluruh wilayah desa di Kecamatan Kebakkramat sudah terlayani fasilitas pendidikan sekolah menengah umum. Namun, wilayah Desa Kaliwuluh bagian utara berada di luar jangkauan pelayanan. Peta jangkauan pelayanan fasilitas pendidikan sekolah menengah umum di Kecamatan Kebakkramat dapat dilihat pada gambar 5.

Gambar 5. Jangkauan Pelayanan SMU di Kecamatan Kebakkramat, (Hasil Analisis, 2014)

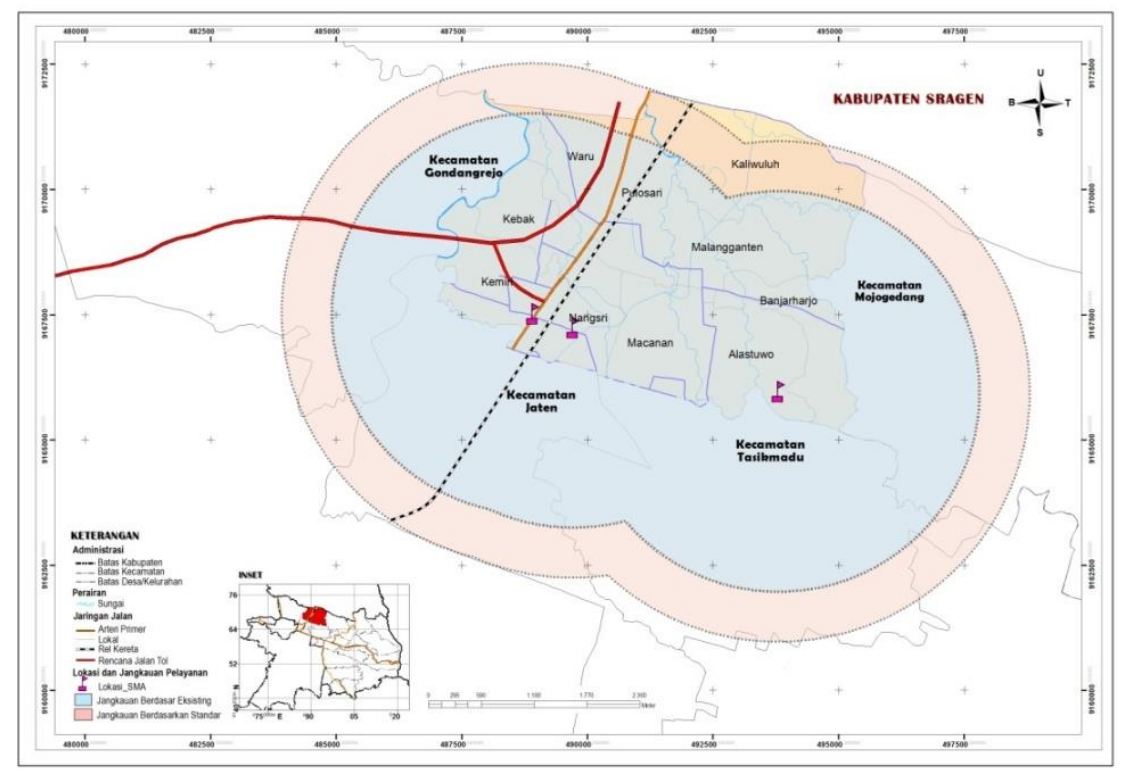


2. Jangkauan Pelayanan Berdasarkan Jarak Lokasi Siswa terhadap Lokasi Sekolah

Jarak lokasi siswa terhadap lokasi sekolah sangat bervariasi. Berdasarkan hasil olah kuesioner, terdapat $22,10 \%$ siswa yang memiliki jarak cukup jauh atau dengan kata lain, lokasi siswa berada di luar jangkauan pelayanan lokasi fasilitas pendidikan sekolah menengah umum (lebih dari 5000 meter). Jarak lokasi siswa yang berada diluar jangkauan pelayanan memiliki rata-rata jarak $7 \mathrm{~km}$ (7000 meter). Peta jarak terjauh lokasi SMU terhadap lokasi siswa dapat dilihat pada gambar 6.

Gambar 6. Jarak Terjauh Lokasi SMU Terhadap Lokasi Siswa, (Hasil Analisis, 2014)

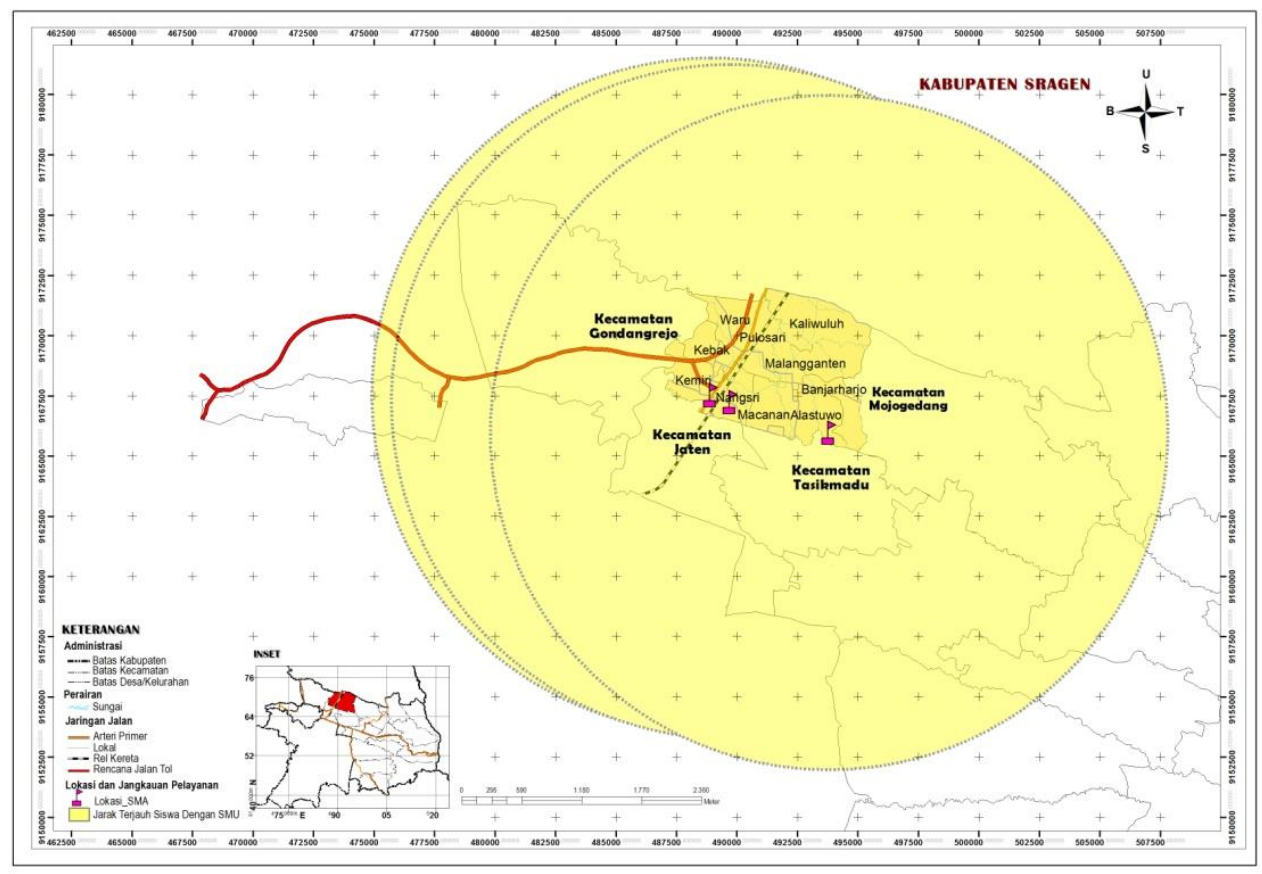

\subsection{Analisis Evaluasi Kesesuaian Lokasi dan Jangkauan Pelayanan SMU di Kecamatan Kebakkramat}

Berdasarkan hasil analisis kesesuaian lokasi dan jangkauan pelayanan sekolah menengah umum di Kecamatan Kebakkramat Kabupaten Karanganyar, lokasi fasilitas pendidikan sekolah menengah umum sudah sesuai dengan fungsi kawasan, persebaran lokasinya, daerah rawan bencana dan tingkat aksesibilitas. Namun, masih terdapat wilayah desa yang berada di luar jangkauan wilayah yakni wilayah Desa Kaliwuluh bagian utara. Seluruh wilayah Kecamatan Kebakkramat memiliki fungsi kawasan budidaya sehingga memenuhi syarat untuk didirikan bangunan termasuk bangunan fasilitas pendidikan. Lokasi fasilitas pendidikan sekolah menengah umum di Kecamatan Kebakkramat berada di kantong-kantong permukiman di Desa Kemiri, Desa Nangsri, dan Desa Alastuwo sehingga memudahkan siswa dalam menjangkau lokasi fasilitas pendidikan.

Meskipun Kecamatan Kebakkramat termasuk wilayah yang rawan akan bencana putting beliung dan banjir, namun lokasi fasilitas pendidikan yang berada di Desa Kemiri, Desa Nangsri, dan Desa Alastuwo tidak dibangun di daerah yang rawan akan bencana. Aksesbilitas lokasi fasilitas pendidikan sekolah menengah umum cukup tinggi dilihat dari jaringan jalan dan moda transportasi umum. Kondisi jalan yang melewati ketiga lokasi fasilitas sekolah menengah umum diKecamatan Kebakkramat cukup baik. SMK Bina Bangsa yang berada di Desa Kemiri dilewati oleh jalan arteri primer yang menghubungkan Kota Solo dengan Kabupaten Sragen. Sementara, meskipun SMA N Kebakkramat dan SMK Widya Mandala yang berada di Desa Nangsri dan Desa Alastuwo hanya dilalui oleh jalan lokal sekunder namun kondisi jalan di kedua wilayah desa ini cukup baik dilihat dari perkerasan jalannya yang berupa aspal dan tidak terdapat keretakan atau lubang-lubang besar.

Moda transportasi umum yang melewati atau menuju lokasi fasilitas pendidikan sekolah menengah umum tersebut cukup beragam. Moda transportasi umum yang melewati SMA N Kebakkramat dan SMK Widya Mandala yang berada di Desa Nangsri dan Desa Alastuwo berupa 
becak, angkudes dan ojek. Sementara moda transportasi umum yang melewati SMK Bina Bangsa berupa angkot, bus kota, dan bus antar kota. Berdasarkan hasil analisis jangkauan pelayanan, seluruh wilayah desa di Kecamatan Kebakkramat sudah terlayani fasilitas pendidikan sekolah menengah umum. Namun, wilayah Desa Kaliwuluh bagian utara berada di luar jangkauan pelayanan. Peta analisis evaluasi kesesuaian lokasi dan jangkauan pelayanan sekolah menengah umum di Kecamatan Kebakkramat dapat dilihat pada gambar 7 .

Gambar 7. Peta Analisis Evaluasi Kesesuaian Lokasi dan Jangkauan Pelayanan SMU Kecamatan Kebakkramat (Hasil Analisis, 2014)

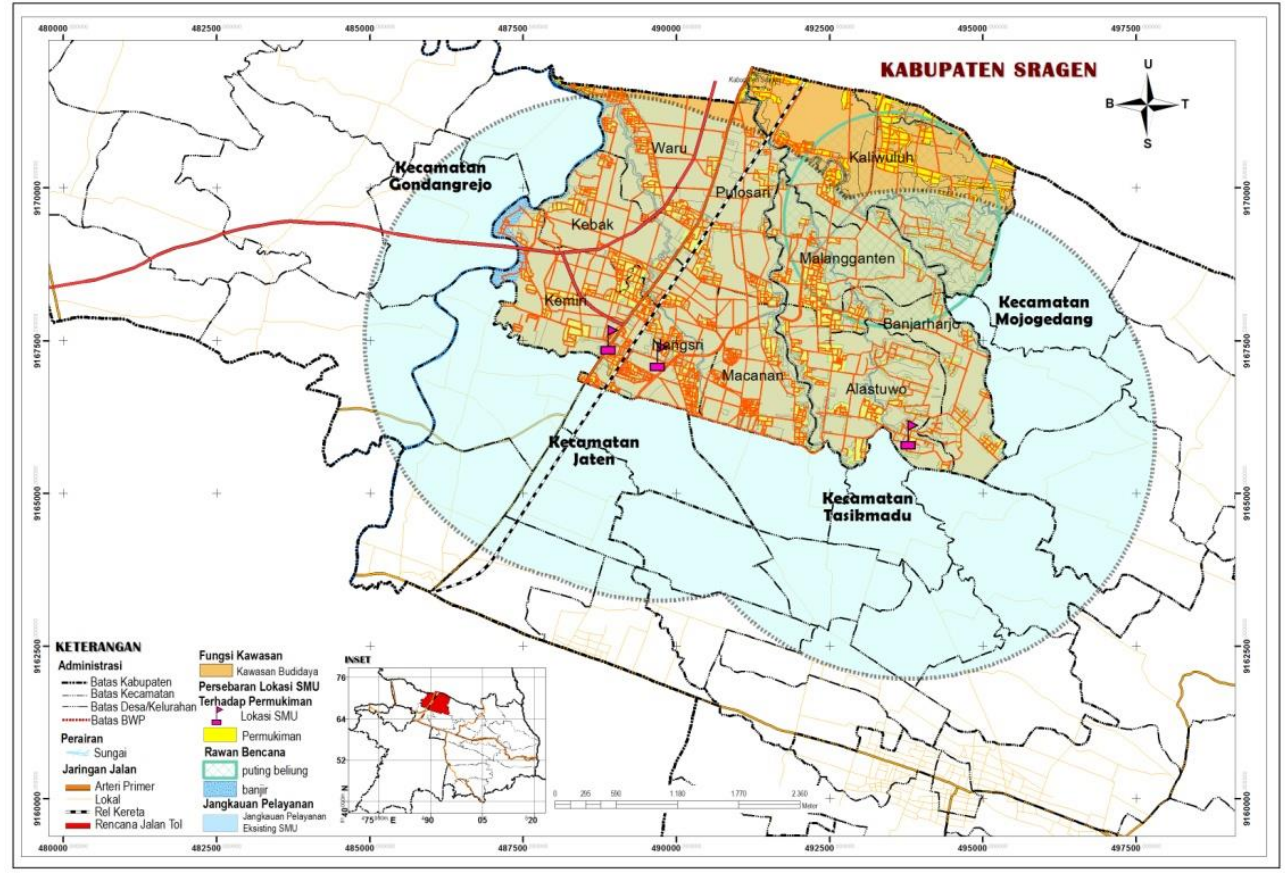

\section{KESIMPULAN DAN REKOMENDASI}

\subsection{Kesimpulan}

Hasil penelitian menunjukkan bahwa dilihat dari kesesuaian lokasi, fasilitas pendidikan sekolah menengah umum di Kecamatan Kebakkramat Kabupaten Karanganyar sudah sesuai dengan parameter yang digunakan yakni berada pada kawasan budidaya, berada dilingkungan kawasan permukiman, tidak berada di daerah rawan bencana, dan memiliki aksesbilitas yang tinggi. Fungsi kawasan Kecamatan Kebakkramat seluruhnya merupakan kawasan budidaya. Lokasi fasilitas pendidikan sekolah menengah umum yang berada di Desa Kemiri, Desa Nangsri, dan Desa Alastuwo berada di lingkungan kawasan permukiman sehingga lokasi fasilitas pendidikan mudah dijangkau oleh siswa. Meskipun Desa Kemiri rawan terhadap bencana banjir, namun lokasi SMK Bina Bangsa yang berada di wilayah tersebut tidak termasuk ke dalam daerah rawan bencana banjir. Lokasi SMK Widya Mandala dan SMA Negeri Kebakkramat yang berada di Desa Nangsri, dan Desa Alastuwo dekat dengan jalan lokal yang dilewati oleh transportasi umum seperti angkudes, ojek dan becak. Sementara, lokasi SMK Bina Bangsa yang berada di Desa Kemiri dekat dengan jalan arteri primer dan di lewati oleh angkutan kota sehingga lokasi fasilitas pendidikan sekolah menengah umum di Kecamatan Kebakkramat dapat diakses oleh siswa dengan mudah. Dilihat dari jangkauan pelayanannya, lokasi fasilitas pendidikan sekolah menengah umum di Kecamatan Kebakkramat sudah mampu dijangkau oleh siswa yang memanfaatkan fasilitas pendidikan tersebut. Masingmasing lokasi fasilitas pendidikan sekolah menengah umum di Kecamatan Kebakkramat memiliki radius jangkauan $4000-5000$ meter. 


\subsection{Rekomendasi}

Berdasarkan hasil penelitian tentang evaluasi kesesuaian lokasi dan jangkauan pelayanan sekolah menengah umum di Kecamatan Kebakkramat maka dapat dirumuskan suatu rekomendasi berupa penambahan fasilitas pendidikan sekolah menengah umum di Kecamatan Kebakkramat. Penambahan fasilitas pendidikan sekolah menengah umum bertujuan untuk menyediakan fasilitas pedidikan bagi siswa yang bersekolah di SMK Bina Bangsa, SMK Widya Mandala dan SMA Negeri Kebakkramat yang memiliki radius jangkauan pelayanan lebih dari 5000 meter.

\section{DAFTAR PUSTAKA}

Bintaro, R. 1969. Interaksi Desa Kota dan Permasalahannya. Jakarta: Ghalia Indonesia.

Kecamatan Kebakkramat Dalam Angka Tahun 2013.

Peraturan Pemerintah No 47 tahun 2008 tentang Wajib Belajar.

SK Menteri Kehutanan No. 837/UM/11/1980 dan No.683/KPTS/UM/8/1982.

SK Menteri Pekerjaan Umum No. 20/KPTS/1986.

SK No 77/KPTS/Db/1990 Tentang Petunjuk Teknis Perencanaan Dan Penyusunan Program Jalan Kabupaten.

Tap MPRS No XXVI/MPRS/1966.

Undang-undang nomor 24 tahun 2007 tentang Penaggulangan Bencana. 